Check for updates

Cite this: RSC Adv., 2019, 9, 11493

Received 19th January 2019

Accepted 1st March 2019

DOI: $10.1039 / \mathrm{c} 9 \mathrm{ra} 00478 \mathrm{e}$

rsc.li/rsc-advances

\title{
New antiproliferative germacranolides from Carpesium divaricatum $\uparrow$
}

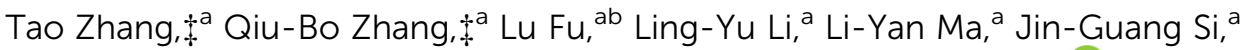 \\ Hong-Wu Zhang, ${ }^{a}$ Jian-He Wei, ${ }^{a}$ Shi-Shan $\mathrm{Yu}^{\mathrm{c}}$ and Zhong-Mei Zou (DD *a
}

Six new highly oxygenated (2-7) and one known (1) germacranolides were isolated from the whole plant of Carpesium divaricatum. The planar structures and relative configurations of the new compounds were determined by detailed spectroscopic analysis. The absolute configurations of 1 and 3 were established by circular dichroism (CD) and X-ray crystallographic analyses, and the stereochemistry of the new compounds 2 and 4-6 were determined by similar CD data to 1 and 3 , respectively. All isolates were evaluated for their antiproliferative activities against three human tumor cell lines, and compounds 3 and 6 show antiproliferative activities against HeLa and Hep G2 cells with $\mathrm{IC}_{50}$ values of $4.13-8.37 \mu \mathrm{M}$. Intensive mechanism study showed that 3 caused cell-cycle arrest at the S/G2 phase and induced apoptosis in Hep G2 cells through a mitochondria-related pathway.

\section{Introduction}

Lately, liver cancer has emerged as the most common malignant tumor in the digestive system, and is recognized as the second leading cancer responsible for mortality in men. ${ }^{1}$ China is a high incidence area of liver cancer, and its incidence rate is 1.5 times the world average level. ${ }^{2}$ Chemotherapy is an effective therapy for liver cancer in surgical treatment. However, the therapeutic effect is usually poor due to the low selectivity and toxicity of chemotherapy drugs., ${ }^{3,4}$

The genus Carpesium belongs to the family Asteraceae with 25 species distributed across Asia and Europe, particularly in southwest China. ${ }^{5,6}$ Sesquiterpenoids were considered as the characteristic constituents of this genus with diverse bioactivities such as cytotoxic, anti-inflammatory, and anti-parasitic activities. ${ }^{6}$ As an important member of this genus, Carpesium divaricatum Sieb.et Zucc is widely distributed in China, traditionally used for the treatment of fevers, colds, bruises, insect bites and inflammatory diseases. ${ }^{7-12}$ Previous investigations of

a Institute of Medicinal Plant Development, Chinese Academy of Medical Sciences, Peking Union Medical College, Beijing 100193, P. R. China. E-mail: zmzou@implad. ac.cn; Fax: +86-10-57833290; Tel: +86-10-57833290

${ }^{b}$ School of Pharmacy, Henan University of Traditional Chinese Medicine, Zhengzhou 450008, P. R. China

'Institute of Materia Medica, Chinese Academy of Medical Sciences, Peking Union Medical College, Beijing 100150, P. R. China

$\dagger$ Electronic supplementary information (ESI) available: ${ }^{1} \mathrm{H}$ NMR, ${ }^{13} \mathrm{C}$ NMR, 2D NMR, UV, IR, HRESIMS and CD spectra of compounds 1-7, and X-ray data of compounds 1 and 3. CCDC 1585969 and 1841157. For ESI and crystallographic data in CIF or other electronic format see DOI: 10.1039/c9ra00478e

$\$$ These authors contributed equally to this study. this plant reported the isolation of germacranolides. ${ }^{11-15}$ The potential values of germacranolides to treat cancer and inflammatory diseases from the genera Carpesium, Inula, and Allagopappus have drawn increasing attention..$^{\mathbf{8 , 1 2 - 2 6}}$

In our continuing effort to search for bioactive constituents from $C$. divaricatum, highly oxygenated germacranolides attracted our attention due to their structural diversity. Seven highly oxygenated germacranolides including six new ones (27) were identified in the current investigation. These highly oxygenated germacranolides contains as many as eight stereogenic centers. NOESY spectrum, circular dichroism (CD) method and X-ray data analysis were used to confirm their relative and absolute configurations.

Notably, compounds 1-2 have opposite configurations at C-8 compared to subtype III we previously reported, indicating an incomplete structural formula of subtype III. ${ }^{27}$ In order to show the universality of structural formula, it is suggested that the configurations at C-4, C-5 and C-8 of subtype III should be depicted as shown (Fig. 1). Similarly, the main differences between compounds 3-6 and subtype IV, and compound 7 and subtype I are the interchange linkage groups at C-8/C-9 and the opposite configurations at C-10, respectively. ${ }^{27}$ The configurations at C-6/C-8/C-9 in subtypes I and II, the configurations at C- $4 / \mathrm{C}-5 / \mathrm{C}-8 / \mathrm{C}-9$, and the substituted groups at C-8/C-9 in subtype IV were revised as shown in this paper.

Furthermore, we screened the isolated compounds for the growth inhibition effect in three tumor cell lines, and then characterized the possible mechanism. It was found that $\mathbf{3}$ and 6 exhibited potent cytotoxicity against human cervical cancer (HeLa) and hepatocellular cancer (Hep G2) cell lines, respectively. Besides, compound 3 induced apoptosis and cell cycle arrest in Hep G2 cells Fig. 2. 


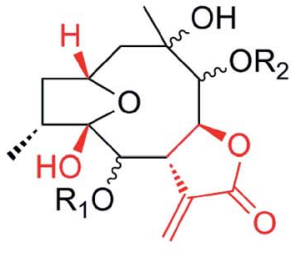

(I)

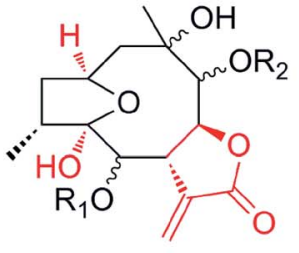

(II)

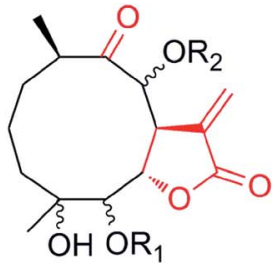

(III)

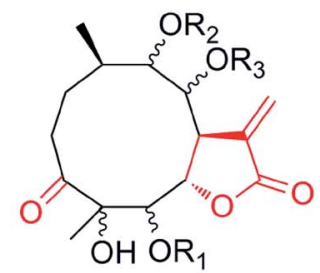

(IV)

Fig. 1 Four subtypes of germacranolides.

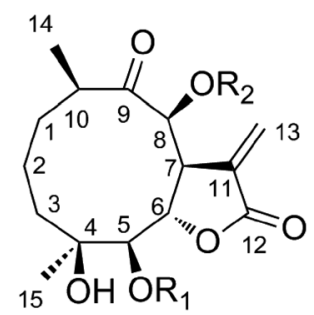

1<smiles>CC(=O)C(C)C</smiles>

2<smiles>CC(=O)C(C)C</smiles>

$\mathrm{R}_{2}$<smiles>CC(=O)C(C)C</smiles><smiles>C=C(C)C(C)=O</smiles>

3<smiles>CC(=O)C(C)C</smiles>

4<smiles>CC(=O)C(C)C</smiles>

5<smiles>C/C=C(/C)C(C)=O</smiles>

6<smiles>CC(=O)C(C)C</smiles>

$\mathrm{R}_{2}$<smiles>CC(=O)C(C)=C[13CH3]</smiles>

$\mathrm{H}$<smiles>CC(=O)CC(C)C</smiles>

$\mathrm{H}$<smiles>C/C=C(/C)C(C)=O</smiles>

$\mathrm{H}$

Fig. 2 Chemical structures of compounds 1-7.

\section{Results and discussion}

\section{Structural elucidation}

An $95 \%$ ethanol extract of the whole plant of $C$. divaricatum was subjected to repeated silica gel, MCI gel, Sephadex LH-20 and semi-prepare HPLC to afford six new highly oxygenated germacranolides (2-7) and one known analogue (1).

Cernuumolide I (1) was identified by comparison of MS, NMR data, as well as optical rotation data with those reported. ${ }^{28}$ Its absolute configuration was further confirmed by CD spectrum (see ESI Fig. C1 $\dagger$ ) and X-ray diffraction (Fig. 3).

Compound 2 was obtained as white needles. The molecular formula was assigned as $\mathrm{C}_{23} \mathrm{H}_{32} \mathrm{O}_{8}$ on the basis of the positiveion HRESIMS peak at $\mathrm{m} / \mathrm{z} 459.1992[\mathrm{M}+\mathrm{Na}]^{+}$, together with its ${ }^{1} \mathrm{H}$ and ${ }^{13} \mathrm{C}$ NMR data (Tables 1 and 2). Its IR spectrum showed hydroxyl $\left(3514 \mathrm{~cm}^{-1}\right)$ and carbonyl $\left(1748 \mathrm{~cm}^{-1}\right)$ absorptions.
The ${ }^{1} \mathrm{H}$ and ${ }^{13} \mathrm{C}$ NMR spectra of 2 showed an $\alpha$-methylene- $\gamma$ lactone at $\delta_{\mathrm{H}} 6.34(1 \mathrm{H}, \mathrm{d}, J=2.4 \mathrm{~Hz}, \mathrm{Ha}-13)$ and $6.14(1 \mathrm{H}, \mathrm{d}, J=$ $2.4 \mathrm{~Hz}, \mathrm{Hb}-13), \delta_{\mathrm{C}} 137.3$ (C-11), 125.1 (C-13) and 171.3 (C-12); three carbonyl carbons at $\delta_{\mathrm{C}} 211.3(\mathrm{C}-9), 179.0\left(\mathrm{C}-1^{\prime}\right)$ and 167.0 (C-1"); one oxygenated tertiary carbon at 73.7 (C-4); five methines including three oxygenated ones at $\delta_{\mathrm{H}} 4.66(1 \mathrm{H}, \mathrm{d}, J=$ $6.6 \mathrm{~Hz}, \mathrm{H}-5), 4.72(1 \mathrm{H}, \mathrm{dd}, J=6.6,1.8 \mathrm{~Hz}, \mathrm{H}-6), 4.19(1 \mathrm{H}, \mathrm{m}, \mathrm{H}-$ 7), $5.46(1 \mathrm{H}, \mathrm{d}, J=1.8 \mathrm{~Hz}, \mathrm{H}-8)$ and $3.15(1 \mathrm{H}, \mathrm{m}, \mathrm{H}-10), \delta_{\mathrm{C}} 79.1$ (C-5), 73.5 (C-6), 45.4 (C-7), 83.4 (C-8), and 44.0 (C-10); and two methyl groups at $\delta_{\mathrm{H}} 1.14\left(3 \mathrm{H}, \mathrm{d}, J=7.2 \mathrm{~Hz}, \mathrm{CH}_{3}-14\right), 1.16(3 \mathrm{H}, \mathrm{s}$, $\left.\mathrm{CH}_{3}-15\right)$. These signals $\left({ }^{1} \mathrm{H}\right.$ and ${ }^{13} \mathrm{C}$ NMR data) implied that the structure of 2 was similar to that of 1 except that the isobutyryloxy group of $\mathbf{1}$ was replaced by a 2-methacryloyloxy group at $\mathrm{C}-8$ in 2 , which was further confirmed by the ${ }^{1} \mathrm{H}^{1}{ }^{1} \mathrm{H}$ COSY, HSQC, and HMBC spectra (Fig. 4). On the basis of these data, the planar structure of 2 was established. 


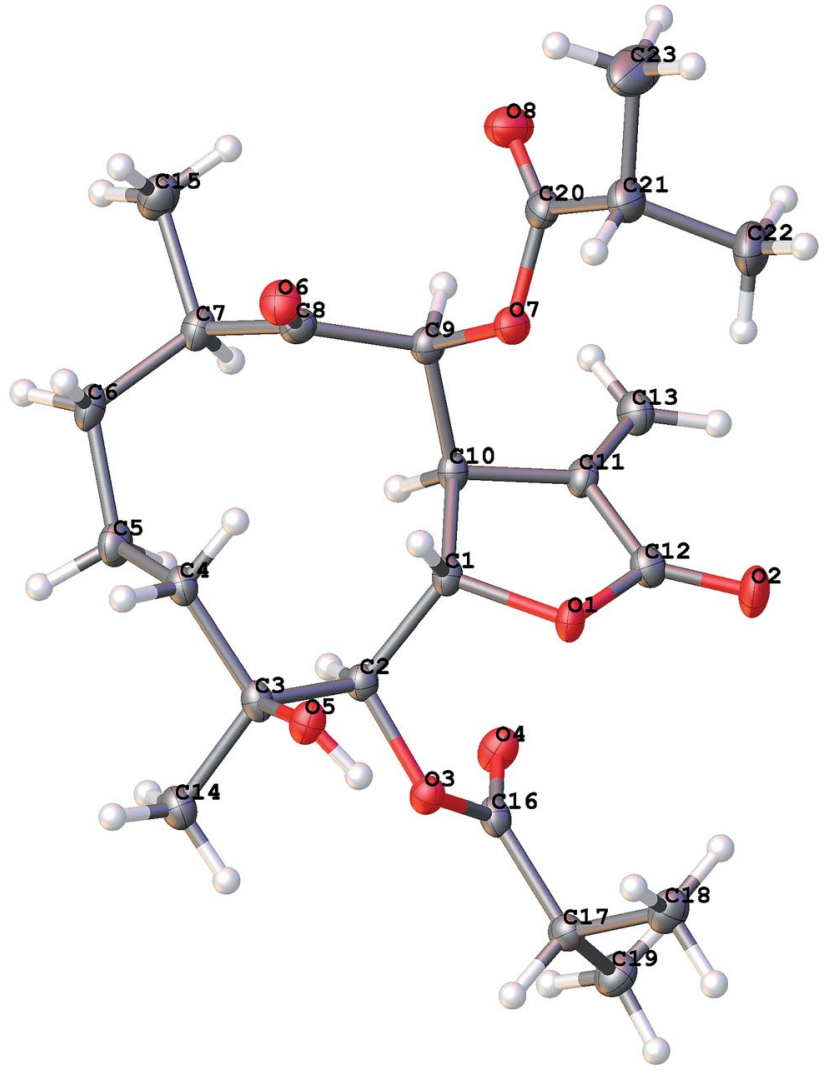

Fig. 3 X-ray ORTEP drawing of 1.
The relative configuration of 2 was determined by analysis of NOESY data. The key NOE correlations of $\mathrm{H}-8 / \mathrm{H}-7, \mathrm{H}-7 / \mathrm{H}-5, \mathrm{H}-7 /$ $\mathrm{H}-10, \mathrm{H}-8 / \mathrm{H}_{3}-14$, and $\mathrm{H}-5 / \mathrm{H}_{3}-15$ indicated that 2 had the same relative configuration as $\mathbf{1}$ (Fig. 5). The CD spectrum (see ESI Fig. C1 $\dagger$ ) of 2 exhibited two positive Cotton effects at near $254 \mathrm{~nm}(\alpha$-methylene- $\gamma$-lactone region) and $294 \mathrm{~nm}$ (ketone $\mathrm{n}$, $\pi^{*}$ region), which closely resembled those of 1 , supporting $6 S, 7 S$ configuration. ${ }^{25}$ Similar NOESY and CD data of 2 and 1 assigned the absolute configuration of 2 as $4 S, 5 R, 6 S, 7 S, 8 S$, and $10 R$. Thus, the structure of compound 2 was determined as shown, named 8-isodivarolide C.

The molecular formula of compound 3 was assigned as $\mathrm{C}_{24} \mathrm{H}_{34} \mathrm{O}_{9}$ by positive-ion HRESIMS ion at $m / z$ 489.2101 [M $+\mathrm{Na}$ ]. The ${ }^{1} \mathrm{H}$ and ${ }^{13} \mathrm{C}$ NMR data implied that the structure of 3 was similar to those of the known compound incaspitolide $\mathrm{D},{ }^{27}$ except that the angeloyloxy group at C-9 in 3 was observed in place of an isobutyryloxy group in incaspitolide $\mathrm{D}$, which was further confirmed by the ${ }^{1} \mathrm{H}-{ }^{1} \mathrm{H}$ COSY, HSQC, and HMBC spectra (Fig. 4). The relative configuration of 3 was determined by analysis of ROESY data. The key NOE correlations of $\mathrm{H}-8 / \mathrm{H}-6$, $\mathrm{H}-7 / \mathrm{H}-5, \mathrm{H}-5 / \mathrm{H}_{3}-15, \mathrm{H}-7 / \mathrm{H}-9$, and $\mathrm{H}-9 / \mathrm{H}-10$ indicated that 3 had the same relative configuration as incaspitolide $\mathrm{D}$ (Fig. 5). The CD spectrum (see ESI Fig. C2 $\dagger$ ) of 3 exhibited two negative Cotton effects at near $220 \mathrm{~nm}$ ( $\alpha$-methylene- $\gamma$-lactone region) and $310 \mathrm{~nm}$ (ketone $\mathrm{n}, \pi^{*}$ region), which closely resembled those of incaspitolide $\mathrm{D}$, supporting $7 R$ configuration. ${ }^{\mathbf{1 9 , 2 9 , 3 0}}$ Fortunately, a suitable crystal was obtained for X-ray diffraction to confirm the absolute configuration. The X-ray

Table $1{ }^{1} \mathrm{H}$ NMR spectroscopic data for compounds $2-7$ ( $\delta$ in ppm, $\mathrm{J}$ in $\mathrm{Hz}$ )

\begin{tabular}{|c|c|c|c|c|c|c|}
\hline No. & $2^{a}$ & $3^{a}$ & $4^{b}$ & $5^{b}$ & $6^{b}$ & $7^{b}$ \\
\hline $1 \mathrm{a}$ & $1.71 \mathrm{o}^{c}$ & $1.88 \mathrm{~m}$ & $1.89 \mathrm{~m}$ & $1.90 \mathrm{~m}$ & $1.94 \mathrm{~m}$ & $2.59 \mathrm{~m}$ \\
\hline $1 b$ & $1.71 \mathrm{o}$ & $1.73 \mathrm{~m}$ & $1.71 \mathrm{~m}$ & $1.72 \mathrm{~m}$ & $1.76 \mathrm{~m}$ & $1.55 \mathrm{~d}(5.0)$ \\
\hline $2 \mathrm{a}$ & $1.72 \mathrm{~m}$ & 3.84 br d (11.4) & $3.76 \mathrm{~m}$ & $3.77 \mathrm{~m}$ & $3.83 \mathrm{~m}$ & $4.55 \operatorname{td}(8.0,2.0)$ \\
\hline $2 b$ & $1.24 \mathrm{~m}$ & $2.24 \mathrm{o}$ & $2.30 \mathrm{~m}$ & $2.31 \mathrm{~m}$ & $2.35 \mathrm{~m}$ & \\
\hline $3 a$ & $1.51 \mathrm{~m}$ & & & & & $2.51 \mathrm{~m}$ \\
\hline $3 b$ & $1.33 \mathrm{~m}$ & & & & & $1.29 \mathrm{~m}$ \\
\hline 4 & & & & & & $2.26 \mathrm{~m}$ \\
\hline 5 & $4.66 \mathrm{~d}(6.6)$ & 5.41 dd $(9.6,1.8)$ & $5.20 \mathrm{dd}(8.0,2.0)$ & $5.18 \mathrm{~d}(10.0)$ & $5.30 \mathrm{~d}(10.0)$ & \\
\hline 6 & 4.72 dd $(6.6,1.8)$ & 4.70 dd $(9.6,6.6)$ & $4.88 \mathrm{dd}(8.0,4.0)$ & $4.90 \mathrm{dd}(10.0,5.0)$ & 4.95 dd $(10.0,5.0)$ & $3.75 \mathrm{~d}(10.0)$ \\
\hline 7 & $4.19 \mathrm{~m}$ & $3.07 \mathrm{~m}$ & $3.11 \mathrm{~m}$ & $3.14 \mathrm{~m}$ & $3.17 \mathrm{~m}$ & $3.26 \mathrm{~m}$ \\
\hline 8 & $5.46 \mathrm{~d}(1.8)$ & $4.47 \mathrm{~d}(10.2)$ & $5.56 \mathrm{~d}(8.5)$ & $5.65 \mathrm{~d}(10.0)$ & $5.68 \mathrm{~d}(10.0)$ & $4.38 \mathrm{dd}(10.0,10.0)$ \\
\hline 9 & & $5.28 \mathrm{~d}(10.2)$ & $3.70 \mathrm{~d}(8.5)$ & $3.76 \mathrm{~d}(10.0)$ & $3.77 \mathrm{~d}(10.0)$ & $5.54 \mathrm{~d}(10.5)$ \\
\hline 10 & $3.15 \mathrm{~m}$ & $2.24 \mathrm{o}$ & $2.06 \mathrm{~m}$ & $2.09 \mathrm{~m}$ & $2.11 \mathrm{~m}$ & \\
\hline $13 \mathrm{a}$ & $6.34 \mathrm{~d}(2.4)$ & $6.35 \mathrm{~d}(3.0)$ & $6.33 \mathrm{~d}(3.0)$ & $6.32 \mathrm{~d}(3.0)$ & $6.34 \mathrm{~d}(3.0)$ & $6.11 \mathrm{~d}(3.5)$ \\
\hline $13 b$ & $6.14 \mathrm{~d}(2.4)$ & $5.72 \mathrm{~d}(3.0)$ & $5.66 \mathrm{~d}(3.0)$ & $5.70 \mathrm{~d}(3.0)$ & $5.70 \mathrm{~d}(3.0)$ & $6.05 \mathrm{~d}(3.5)$ \\
\hline 14 & $1.14 \mathrm{~d}(7.2)$ & $1.00 \mathrm{~d}(6.6)$ & $1.11 \mathrm{~d}(6.0)$ & $1.11 \mathrm{~d}(6.5)$ & $1.12 \mathrm{~d}(6.5)$ & $1.20 \mathrm{~s}$ \\
\hline 15 & $1.16 \mathrm{~s}$ & $1.25 \mathrm{~s}$ & $1.22 \mathrm{~s}$ & $1.22 \mathrm{~s}$ & $1.25 \mathrm{~s}$ & $1.04 \mathrm{~d}(6.5)$ \\
\hline $2^{\prime}$ & $2.68 \mathrm{~m}$ & $2.72 \mathrm{~m}$ & $2.69 \mathrm{~m}$ & $2.68 \mathrm{~m}$ & & \\
\hline $3^{\prime}$ & $1.20 \mathrm{~d}(7.2)$ & $1.26 \mathrm{~d}(6.6)$ & $1.22 \mathrm{~d}(6.0)$ & $1.22 \mathrm{~d}(6.0)$ & $6.08 \mathrm{qq}(7.0,1.5)$ & \\
\hline $4^{\prime}$ & $1.18 \mathrm{~d}(7.2)$ & $1.25 \mathrm{~d}(6.6)$ & $1.23 \mathrm{~d}(6.0)$ & $1.23 \mathrm{~d}(6.0)$ & $1.97 \mathrm{q}(1.5)$ & \\
\hline $5^{\prime}$ & & & & & $1.96 \mathrm{dq}(7.0,1.5)$ & \\
\hline $2^{\prime \prime}$ & & & $2.16 \mathrm{~m}$ & & & $2.61 \mathrm{~m}$ \\
\hline \multirow[t]{2}{*}{$3^{\prime \prime}$} & $6.08 \mathrm{dq}(2.4,1.2)$ & & & & & \\
\hline & $5.67 \mathrm{dq}(2.4,1.2)$ & 6.17 qq $(7.2,1.8)$ & $1.98 \mathrm{~m}$ & $6.09 \mathrm{qq}(7.0,1.5)$ & $6.17 \mathrm{qq}(7.0,1.5)$ & $1.20 \mathrm{~d}(5.5)$ \\
\hline $4^{\prime \prime}$ & $1.90 \mathrm{br} \mathrm{s}$ & $1.97 \mathrm{dq}(1.8,1.2)$ & $0.89 \mathrm{~d}(5.0)$ & $1.79 \mathrm{q}(1.5)$ & $1.80 \mathrm{q}(1.5)$ & $1.19 \mathrm{~d}(6.0)$ \\
\hline $5^{\prime \prime}$ & & $2.01 \mathrm{dq}(7.2,1.8)$ & $0.90 \mathrm{~d}(5.0)$ & $1.90 \mathrm{dq}(7.0,1.5)$ & $1.97 \mathrm{dq}(7.0,1.5)$ & \\
\hline
\end{tabular}

${ }^{a}$ Measured at $600 \mathrm{MHz}$ in methanol- $d_{4} \cdot{ }^{b}$ Measured at $500 \mathrm{MHz}$ in methanol- $d_{4} \cdot{ }^{c}$ Overlapped with other signals. 
Table $2{ }^{13} \mathrm{C}$ NMR spectroscopic data for compounds $2-7$ ( $\delta$ in ppm)

\begin{tabular}{|c|c|c|c|c|c|c|}
\hline No. & $2^{a}$ & $3^{a}$ & $4^{b}$ & $5^{b}$ & $6^{b}$ & $7^{b}$ \\
\hline 1 & 34.1 & 25.5 & 24.1 & 24.5 & 24.1 & 46.3 \\
\hline 2 & 24.2 & 32.8 & 34.8 & 35.2 & 34.9 & 70.9 \\
\hline 3 & 37.5 & 217.6 & 217.5 & 217.5 & 217.8 & 38.7 \\
\hline 4 & 73.7 & 80.4 & 80.2 & 80.2 & 80.3 & 35.5 \\
\hline 5 & 79.1 & 78.1 & 78.1 & 78.1 & 78.0 & 106.5 \\
\hline 6 & 73.5 & 80.0 & 79.8 & 79.9 & 79.9 & 68.1 \\
\hline 7 & 45.4 & 41.6 & 40.1 & 40.2 & 40.2 & 49.4 \\
\hline 8 & 83.4 & 70.5 & 76.0 & 76.2 & 76.2 & 77.3 \\
\hline 9 & 211.3 & 78.5 & 75.1 & 75.3 & 75.3 & 79.6 \\
\hline 10 & 44.0 & 30.0 & 30.7 & 30.9 & 30.9 & 71.9 \\
\hline 11 & 137.3 & 132.7 & 132.6 & 133.0 & 133.1 & 139.0 \\
\hline 12 & 171.3 & 169.6 & 169.2 & 169.2 & 169.3 & 169.9 \\
\hline 13 & 125.1 & 123.9 & 124.6 & 124.6 & 124.6 & 119.4 \\
\hline 14 & 20.4 & 20.0 & 19.8 & 19.8 & 20.2 & 23.2 \\
\hline 15 & 24.2 & 23.3 & 23.1 & 23.1 & 23.5 & 12.0 \\
\hline $1^{\prime}$ & 179.0 & 176.4 & 176.4 & 176.4 & 167.1 & \\
\hline $2^{\prime}$ & 35.0 & 34.0 & 33.9 & 34.0 & 127.4 & \\
\hline $3^{\prime}$ & 19.2 & 18.0 & 18.0 & 18.0 & 138.2 & \\
\hline $4^{\prime}$ & 19.2 & 17.9 & 17.9 & 17.9 & 19.2 & \\
\hline $5^{\prime}$ & & & & & 14.6 & \\
\hline $1^{\prime \prime}$ & 167.0 & 167.7 & 172.9 & 167.4 & 167.5 & 176.1 \\
\hline $2^{\prime \prime}$ & 136.7 & 127.8 & 42.9 & 127.3 & 127.4 & 34.0 \\
\hline $3^{\prime \prime}$ & 127.4 & 137.7 & 25.8 & 138.2 & 138.4 & 17.9 \\
\hline $4^{\prime \prime}$ & 18.1 & 19.4 & 21.6 & 19.2 & 19.3 & 17.9 \\
\hline $5^{\prime \prime}$ & & 14.6 & 21.7 & 14.6 & 14.6 & \\
\hline \multicolumn{7}{|c|}{$\begin{array}{l}{ }^{a} \text { Measured at } 150 \mathrm{MHz} \text { in methanol- } d_{4 \cdot}{ }^{b} \text { Measured at } 125 \mathrm{MHz} \text { in } \\
\text { methanol- } d_{4} \text {. }\end{array}$} \\
\hline
\end{tabular}

crystallographic analysis [flack parameter: -0.07 (9)] established unambiguously the absolute configuration of $\mathbf{1}$ to be $4 R, 5 R, 6 S, 7 R, 8 R, 9 R$, and $10 R$ (Fig. 6). Thus, the structure of compound 3 was established as shown, named cardivarolide $\mathrm{H}$.

Compound 4 possessed molecular formula of $\mathrm{C}_{24} \mathrm{H}_{36} \mathrm{O}_{9}$ based on the HRESIMS ion at $m / z 491.2249[\mathrm{M}+\mathrm{Na}]^{+}$. A comparison of the ${ }^{1} \mathrm{H}$ and ${ }^{13} \mathrm{C}$ NMR data of 4 with those of 3 revealed strong similarity, except that the angeloyloxy group and the hydroxyl group in $\mathbf{3}$ were substituted by a hydroxyl group at C-9 and a 3-methylbutyryloxy group at C-8 in $\mathbf{4}$, respectively. The ${ }^{1} \mathrm{H}-{ }^{1} \mathrm{H}$ COSY, HSQC and HMBC spectra of 4 confirmed this observation, leading to the assignment of its planar structure. Compound $\mathbf{4}$ had the same relative configuration as 3, according to the analysis of their ROESY data. Similar CD data of $\mathbf{4}$ and $\mathbf{3}$ (see ESI Fig. C2 $\dagger$ ) revealed the same absolute configuration of $\mathbf{4}$ as that of $\mathbf{3}$. Thus, the structure of compound 4 was defined as shown, named cardivarolide I.

Compounds 5-6 had molecular formulas of $\mathrm{C}_{24} \mathrm{H}_{34} \mathrm{O}_{9}$, and $\mathrm{C}_{25} \mathrm{H}_{34} \mathrm{O}_{9}$ from their HRESIMS ions at $m / z 489.2107[\mathrm{M}+\mathrm{Na}]^{+}$, and $m / z 501.2103[\mathrm{M}+\mathrm{Na}]^{+}$, respectively. The ${ }^{1} \mathrm{H}$ and ${ }^{13} \mathrm{C}$ NMR data of 5 were similar to those of $\mathbf{4}$, except that the 3-methylbutyryloxy group at C-8 in $\mathbf{4}$ was replaced by an angeloyloxy group in 5. The NMR data of $\mathbf{6}$ were comparable with those of $\mathbf{5}$, except for the presence of an angeloyloxy group in $\mathbf{6}$ instead of the isobutyryloxy group at $\mathrm{C}-5$ in $\mathbf{5}$. These observations were confirmed by analyses of relevant ${ }^{1} \mathrm{H}^{1}{ }^{1} \mathrm{H}$ COSY, HSQC and HMBC data. The relative configurations of 5-6 were determined to be the same as that of $\mathbf{4}$ by comparison of ROESY data for relevant protons. Similar CD data of 5-6 and $\mathbf{4}$ (see ESI Fig. C2 $\dagger$ ) revealed the same absolute configurations of 5-6 as that of 4 . Thus, the structures of compounds 5-6 were established as shown, named cardivarolide $\mathrm{J}$ and cardivarolide $\mathrm{K}$, respectively.

The molecular formula of compound 7 was determined to be $\mathrm{C}_{19} \mathrm{H}_{26} \mathrm{O}_{7}$ by HRESIMS $\left(389.1575[\mathrm{M}+\mathrm{Na}]^{+}\right)$. The ${ }^{1} \mathrm{H}$ and ${ }^{13} \mathrm{C}$ NMR data of 7 implied that the planar structure of 7 was closely related to the known compound $(2 R, 5 S)$-cardivarolide $\mathrm{C},{ }^{14,27}$ but that the residue at C-6 was a hydroxy group in 7. The assignments were also supported by ${ }^{1} \mathrm{H}^{-}{ }^{1} \mathrm{H}$ COSY, HSQC and HMBC spectra (Fig. 4). The relative configuration of 7 was nearly identical with those of $(2 R, 5 S)$-cardivarolide $\mathrm{C}$, except for C-10. In the NOESY spectrum, the key NOE correlations of $\mathrm{H}-2 / \mathrm{H}-4$, $\mathrm{H}_{3}-15 / \mathrm{H}-6, \mathrm{H}-6 / \mathrm{H}-8, \mathrm{H}-8 / \mathrm{H}_{3}-14$, and $\mathrm{H}-7 / \mathrm{H}-9$ indicated $5-\mathrm{OH}$, $\mathrm{H}-7$ and $\mathrm{H}-9$ were attached to the $\beta$-side and $\mathrm{H}_{3}-15, \mathrm{H}-6, \mathrm{H}-8$ and $\mathrm{H}_{3}-14$ to the $\alpha$-side of the ring (Fig. 5). The CD spectrum of 7 exhibited one positive Cotton effects at near $254 \mathrm{~nm}(\alpha$-methylene- $\gamma$-lactone region, see ESI Fig. S7 $\dagger$ ), which closely resembled those of ineupatolide, ${ }^{19}$ suggesting the $2 R, 4 R, 5 S, 6 R, 7 S, 8 S, 9 R$, and $10 R$ absolute configuration for 7 . Thus, the structure of 7 was elucidated as shown, named cardivarolide $\mathrm{L}$.

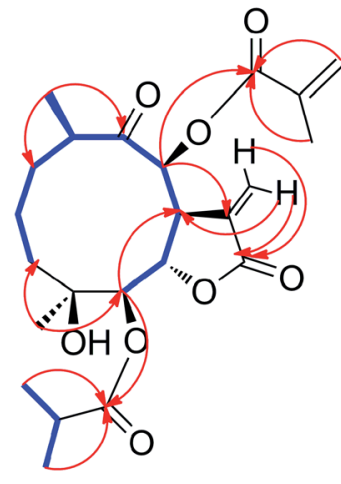

2

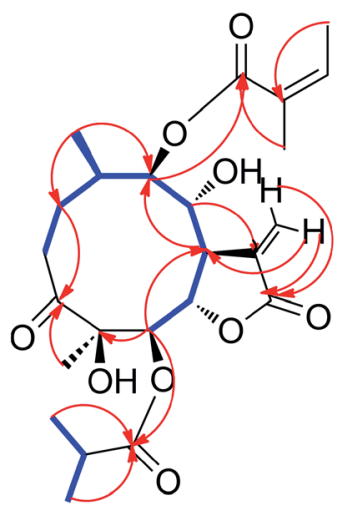

3

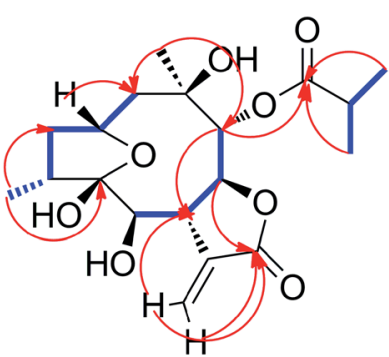

7

Fig. 4 Key ${ }^{1} \mathrm{H}-{ }^{1} \mathrm{H}$ COSY and $\mathrm{HMBC}$ correlations of compounds 2, 3 and 7. 


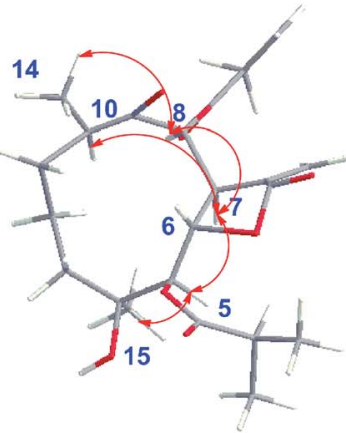

2

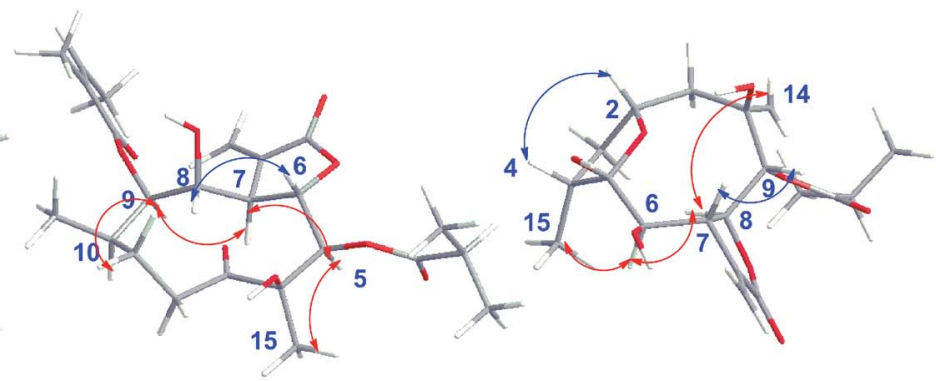

3

7

Fig. 5 Key NOESY correlations of compounds 2, 3 and 7 .

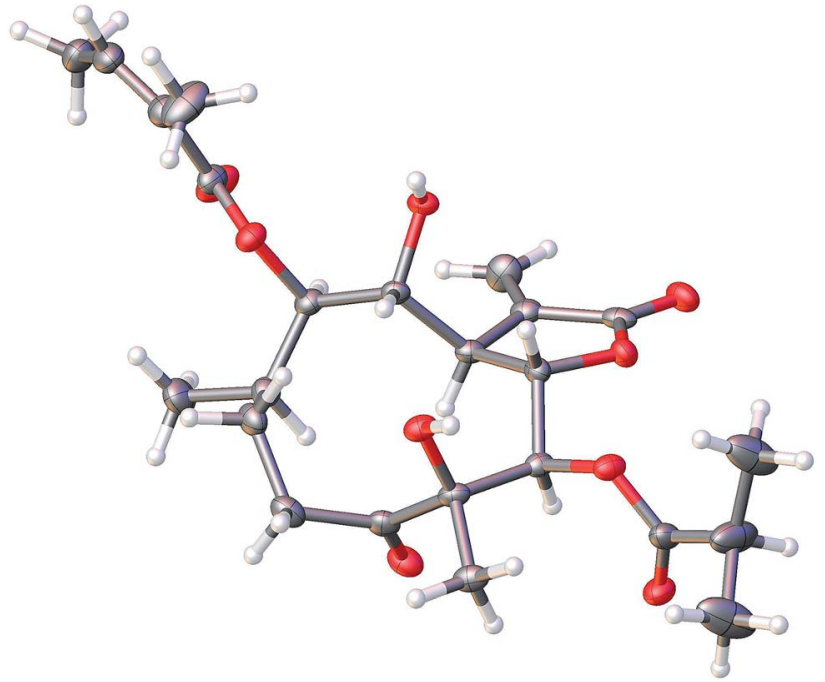

Fig. 6 X-ray ORTEP drawing of 3 .

\section{Cytotoxicity}

All isolated compounds were evaluated for their in vitro cytotoxic activities against human cervical cancer (HeLa), hepatocellular cancer (Hep G2), and lung cancer (A549), using the MTT method with vorinostat as the positive control. The data in Table 3 suggested that new compounds $\mathbf{3}$ and $\mathbf{5}$ exhibited

Table 3 Cytotoxicity of compounds $1-7^{a}$

\begin{tabular}{|c|c|c|c|}
\hline \multirow[b]{2}{*}{ Compound } & \multicolumn{3}{|l|}{$\mathrm{IC}_{50}(\mu \mathrm{M})$} \\
\hline & HeLa & Hep G2 & A549 \\
\hline 1 & $9.05 \pm 0.80$ & $14.03 \pm 0.75$ & $>50$ \\
\hline 2 & $>50$ & $>50$ & $>50$ \\
\hline 3 & $4.13 \pm 0.75$ & $5.93 \pm 0.49$ & $28.96 \pm 1.01$ \\
\hline 4 & $6.18 \pm 0.04$ & $8.99 \pm 1.45$ & $42.73 \pm 1.34$ \\
\hline 5 & $5.88 \pm 0.05$ & $10.66 \pm 1.02$ & $39.87 \pm 1.17$ \\
\hline 6 & $5.08 \pm 0.02$ & $8.37 \pm 0.22$ & $23.67 \pm 0.81$ \\
\hline 7 & $>50$ & $>50$ & $>50$ \\
\hline Vorinostat & $10.90 \pm 3.00$ & $8.82 \pm 0.71$ & $10.65 \pm 0.46$ \\
\hline
\end{tabular}

${ }^{a}$ Values were mean \pm SD. Vorinostat, positive control. Cell lines: HeLa: human cervical cancer, Hep G2: human hepatocellular cancer, A549: human lung cancer. cytotoxicity against HeLa ( $\mathrm{IC}_{50}$ values of 4.13 and $\left.5.08 \mu \mathrm{M}\right)$ and Hep $\mathrm{G} 2\left(\mathrm{IC}_{50}\right.$ values of 5.93 and $\left.8.37 \mu \mathrm{M}\right)$ cell lines compared to the positive control vorinostat $\left(\mathrm{IC}_{50}\right.$ values of 10.90 and 8.82 $\mu \mathrm{M})$, respectively. Considering the amounts of isolated compounds, we chose 3 for further research.

\section{Morphological evaluation of apoptosis}

As shown in Fig. 7, untreated Hep G2 cells exhibited normal growth characteristics (Fig. 7A). Interestingly, we found alterations in the structure, size, and shape of the nuclei in Hep G2 cells treated with $2.0 \mu \mathrm{M} 3$ for 48 h (Fig. 7B), with large cytoplasmic vacuoles, abnormal mitotic figures, multinucleation and formation of large cells being typical (Fig. 7C and D). These hallmarks of cell death, which increased concomitantly with increasing drug concentration, are indicated by red arrows.

\section{Cardivarolide H (3) induces apoptosis in Hep G2 cells}

In order to characterize the apoptosis process of Hep G2 cells induced by cardivarolide $\mathrm{H}$ (3), we examined the numbers of apoptotic cells by Annexin V-FITC/PI apoptosis staining. After $24 \mathrm{~h}$ exposure to different concentrations of 3 , the numbers of apoptotic cells (AV+/PIand $\mathrm{AV}+/ \mathrm{PI}+)$ increased in a dosedependent manner (Fig. 8). These results demonstrated that 3 was effective in the induction of apoptosis in Hep G2 cells.

\section{Cardivarolide $H$ (3) increases G0/G1 arrest of cell cycle in Hep G2 cells}

Hep G2 cells were treated with different concentrations of cardivarolide $\mathrm{H}$ (3) for $24 \mathrm{~h}$, followed by flow cytometry analyses and the cardivarolide $\mathrm{H}$-treated group revealed G0/G1 phase arrest compared with control group (Fig. 9). Fig. 9 revealed the numbers of cells arrested in G0/G1 phase. These results indicated that growth inhibition of $\mathbf{3}$ in Hep G2 cells were partly associated with the induction of G0/G1 arrest in cell cycle.

\section{Experimental section}

\section{General experimental procedures}

Optical rotations were measured on a Perkin-Elmer 241 polarimeter (Perkin-Elmer, Waltham, MA, USA) and UV spectra were 


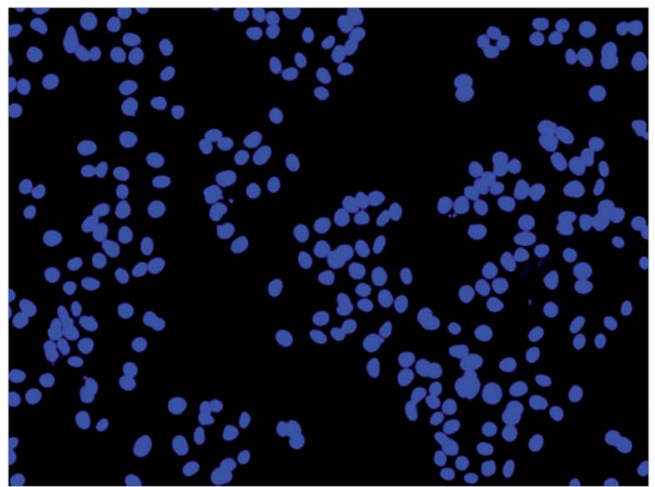

A: Control

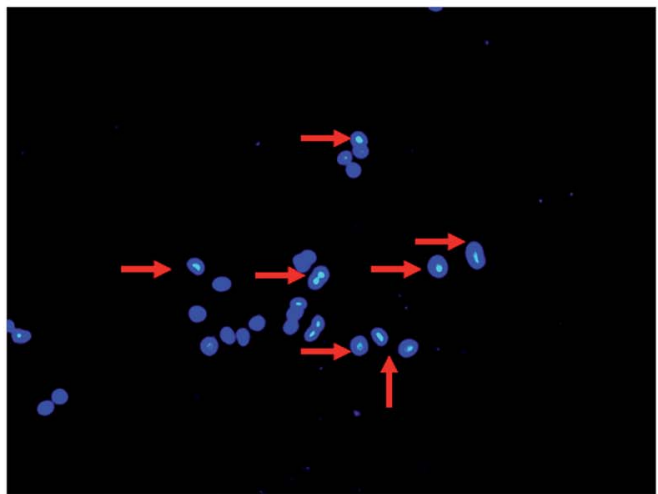

$\mathrm{C}: 4 \mu \mathrm{M}$

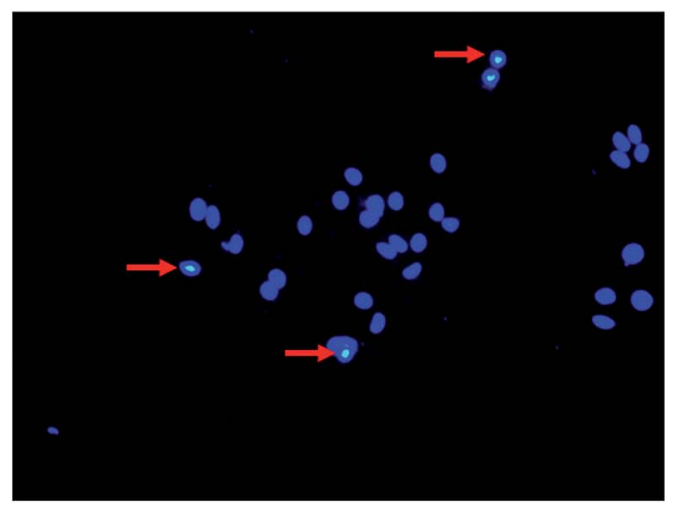

B: $2 \mu \mathrm{M}$

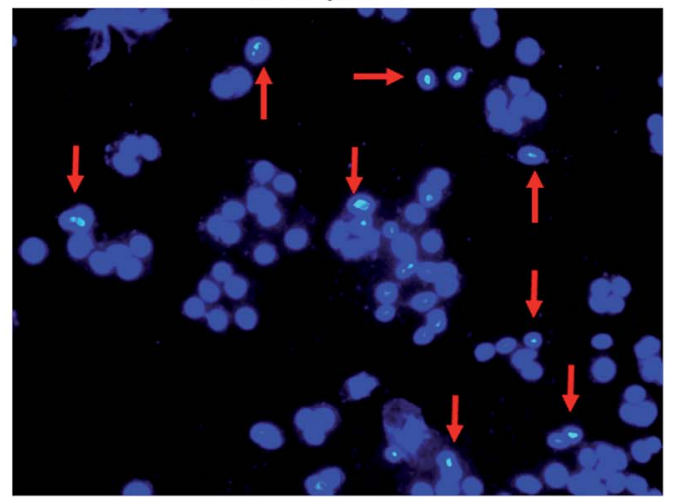

D: $8 \mu \mathrm{M}$

Fig. 7 Chromatin condensation and nuclear fragmentation typical for apoptosis induction were visualized by fluorescence microscopy following Hoechst 33342 staining; (A) control Hep G2 cells; (B) Hep G2 cells treated with $2 \mu$ M 3; (C) Hep G2 cells treated with 4 M 3; (D) Hep G2 cells treated with $8 \mu \mathrm{M} 3$. Magnification $400 \times$.

recorded on Shimadzu UV-2501 PC (Shimadzu, Kyoto, Japan). IR data were recorded using a Shimadzu FTIR-8400S spectrophotometer (Shimadzu, Kyoto, Japan). ${ }^{1} \mathrm{H}$ and ${ }^{13} \mathrm{C}-\mathrm{NMR}$ data were acquired with Bruker 600 and Bruker 500 instruments (Bruker, Rheinstetten, Germany) using the solvent signals as references. HRESIMS data were acquired using Q-TOF analyzer in SYNAPT HDMS system (Waters, Milford, MA, USA). CD spectra were recorded on a JASCO J-815 Spectropolarimeter (Jasco, Tokyo, Japan). X-ray diffraction data were collected on the Agilent GEMINI ${ }^{\mathrm{TM}} \mathrm{E}$ instrument (CrysAlisPro software, Version 1.171.35.11; Agilent, Santa Clara, CA, USA). HPLC was performed using Waters 2535 system (Waters, Milford, MA, USA) with the following components: preparative column, a Daisogel- $\mathrm{C}_{18}-100 \mathrm{~A}$ $(10 \mu \mathrm{m}, 30 \times 250 \mathrm{~mm}$, Chuang Xin Tong Heng Sci. \&Tech., Beijing, China) and a YMC-Pack ODS-A column $(5 \mu \mathrm{m}, 10 \times 250 \mathrm{~mm}$, YMC, Kyoto, Japan); and detector, Waters 2489 UV. Sephadex LH20 (40-70 $\mu \mathrm{m}$, Pharmacia Biotech AB, Uppsala, Sweden), silica gel (60-100, 100-200, and 200-300 mesh) and silica gel GF254 sheets (0.20-0.25 mm) (Qingdao Marine Chemical Plant, Qingdao, China) were used for column chromatography and TLC, respectively. TLC spots were visualized under UV light and by dipping into $5 \% \mathrm{H}_{2} \mathrm{SO}_{4}$ in EtOH followed by heating.

\section{Plant material}

The whole plant of $C$. divaricatum was collected from Enshi, Hubei province of China, in August of 2013. They were identified by Prof. Ben-Gang Zhang of Institute of Medicinal Plant Development. A voucher specimen (no. 20130828) was deposited in the National Compound Library of Traditional Chinese Medicines, Institute of Medicinal Plant Development, Chinese Academy of Medical Sciences and Peking Union Medical College (CAMS \& PUMC), China.

\section{Extraction and isolation}

The air-dried plants $(9 \mathrm{~kg})$ were extracted three times ( 7 days each time) with EtOH- $\mathrm{H}_{2} \mathrm{O}(95: 5)$ at room temperature. The combined extract was concentrated under reduced pressure to furnish a dark brown residue $(570 \mathrm{~g})$, which was suspended in $\mathrm{H}_{2} \mathrm{O}$ and partitioned in turn with petroleum ether (bp 60-90 ${ }^{\circ} \mathrm{C}$ ), EtOAc, and $n-\mathrm{BuOH}$.

The EtOAc extract (207 g) was separated chromatographically on silica gel column $(60-100$ mesh, $16 \times 20 \mathrm{~cm})$ with a gradient mixture of $\mathrm{CH}_{2} \mathrm{Cl}_{2}-\mathrm{MeOH}(100: 1,60: 1,30: 1,15: 1$, and $6: 1)$ as eluent. Five fractions were collected according to TLC analysis. Fraction $\mathrm{A}\left(\mathrm{CH}_{2} \mathrm{Cl}_{2}-\mathrm{MeOH}, 100: 1,140 \mathrm{~g}\right)$ was separated by silica gel column chromatography (CC) (100-200 mesh, $16 \times 20$ $\mathrm{cm})$ with petroleum ether-acetone $(50: 1,25: 1,20: 1,15: 1$, $12: 1,10: 1,7: 1,5: 1,3: 1$, and $1: 1)$ as eluent to give fractions $\mathrm{A}_{1}-\mathrm{A}_{11}$. Fraction $\mathrm{A}_{9}$ (petroleum ether-acetone, $5: 1,30 \mathrm{~g}$ ) was separated by Sephadex LH-20 CC $(5 \times 200 \mathrm{~cm}, \mathrm{MeOH})$ to give Fr. $A_{9} S_{1}-F r . A_{9} S_{3}$. Fraction $A_{9} S_{2}(20 \mathrm{~g})$ was then subjected to MCI gel $\mathrm{CC}(6 \times 50 \mathrm{~cm})$ with a gradient mixture of $\mathrm{MeOH}-\mathrm{H}_{2} \mathrm{O}$ 

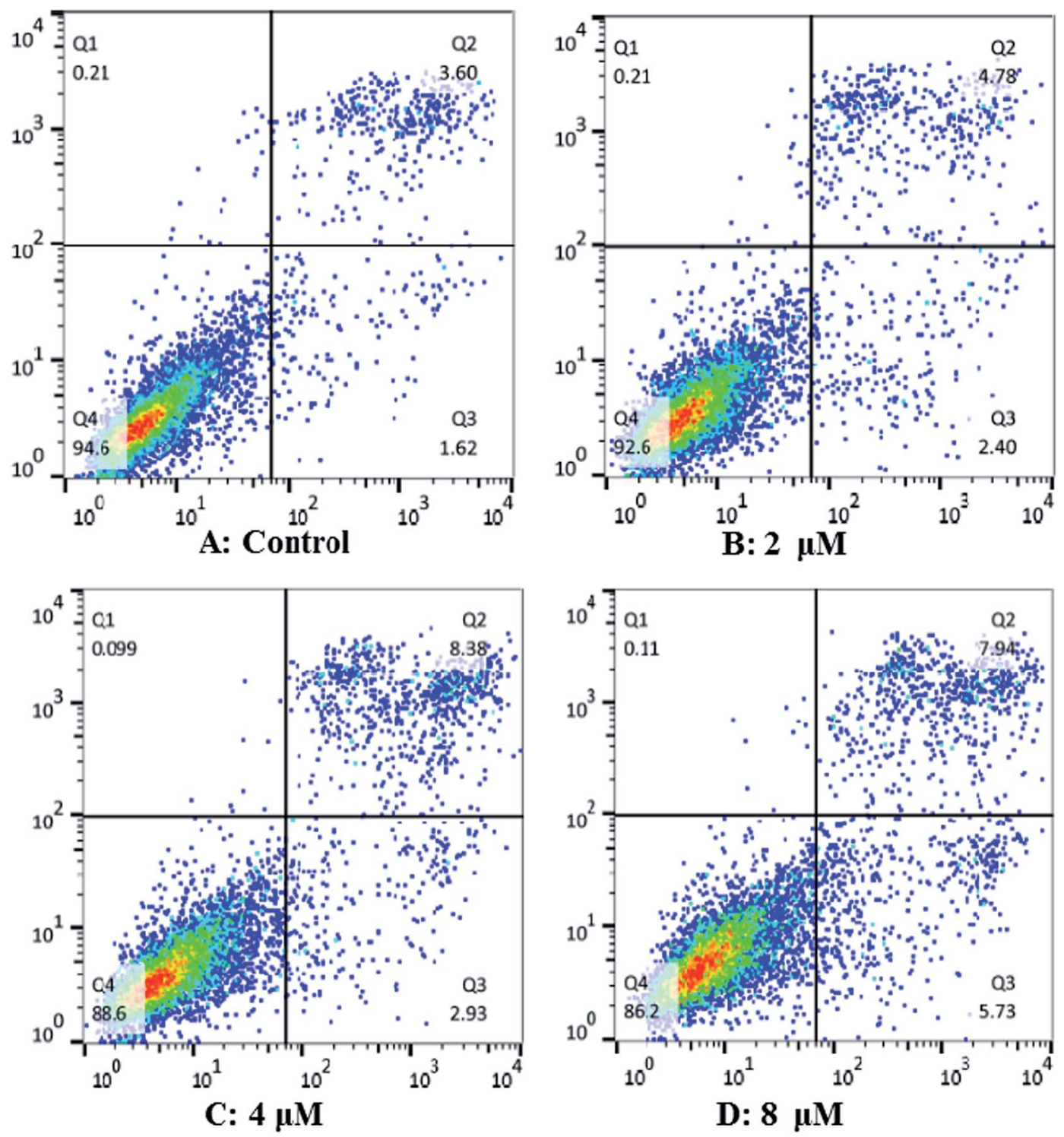

Fig. 8 Cardivarolide H (3) induces apoptosis in Hep G2 cells. (A) Control Hep G2 cells; (B) Hep G2 cells treated with $2 \mu$ M 3; (C) Hep G2 cells treated with $4 \mu \mathrm{M}$ 3; (D) Hep G2 cells treated with $8 \mu \mathrm{M} 3$.

(60:40, $80: 20$, and $100: 0,4000 \mathrm{~mL}$ each) to give three fractions (Fr. $\mathrm{A}_{9} \mathrm{~S}_{2} \mathrm{M}_{1}-$ Fr. $\mathrm{A}_{9} \mathrm{~S}_{2} \mathrm{M}_{3}$ ). Fraction $\mathrm{A}_{9} \mathrm{~S}_{2} \mathrm{M}_{2}(10 \mathrm{~g})$ was further separated chromatographically on silica gel column (100-200 mesh, $5 \times 50 \mathrm{~cm}$ ) with a gradient mixture of petroleum etheracetone (10:1, $7: 1,5: 1,3.5: 1,2: 1$, and $1: 1)$ as eluent, and a total of 200 fractions (Fr. $A_{9} S_{2} M_{2}-1-200,50 \mathrm{~mL}$ each) were collected. Fraction $\mathrm{A}_{9} \mathrm{~S}_{2} \mathrm{M}_{2}-113-123(1 \mathrm{~g})$ were separated by preparative HPLC $\left(20 \mathrm{~mL} \min ^{-1}, 65 \% \mathrm{MeOH}\right.$ in $\left.\mathrm{H}_{2} \mathrm{O}\right)$ and semipreparative HPLC ( $2 \mathrm{~mL} \mathrm{~min}^{-1}, 60-90 \% \mathrm{MeOH}$ in $\mathrm{H}_{2} \mathrm{O}$ for $50 \mathrm{~min} ; 2 \mathrm{~mL} \mathrm{~min}{ }^{-1}, 40-80 \% \mathrm{MeCN}$ in $\mathrm{H}_{2} \mathrm{O}$ for $40 \mathrm{~min}$ ) to yield 3 (25 mg). Fraction $\mathrm{A}_{10}$ (petroleum ether-acetone, $3: 1,40 \mathrm{~g}$ ) was separated by Sephadex LH-20 CC $(5 \times 200 \mathrm{~cm}, \mathrm{MeOH})$ to give Fr. $A_{10} S_{1}-F r . A_{10} S_{3}$. Fraction $A_{10} S_{2}(20 \mathrm{~g})$ was then subjected to MCI gel CC $(6 \times 50 \mathrm{~cm})$ with a gradient mixture of $\mathrm{MeOH}-$ $\mathrm{H}_{2} \mathrm{O}(60: 40,80: 20$, and $100: 0,4000 \mathrm{~mL}$ each) to give three fractions (Fr. $\mathrm{A}_{10} \mathrm{~S}_{2} \mathrm{M}_{1}-$ Fr. $\mathrm{A}_{10} \mathrm{~S}_{2} \mathrm{M}_{3}$ ). Fraction $\mathrm{A}_{10} \mathrm{~S}_{2} \mathrm{M}_{2}(13 \mathrm{~g}$ ) was further separated chromatographically on silica gel column
(200-300 mesh, $5 \times 50 \mathrm{~cm}$ ) with a gradient mixture of $\mathrm{CH}_{2} \mathrm{Cl}_{2}-$ $\mathrm{MeOH}(150: 1,100: 1,50: 1$, and $20: 1)$ as eluent, and a total of 86 fractions (Fr. $\mathrm{A}_{10} \mathrm{~S}_{2} \mathrm{M}_{2}-1-86,200 \mathrm{~mL}$ each) were collected. Fraction $\mathrm{A}_{10} \mathrm{~S}_{2} \mathrm{M}_{2}-34-50$ (1.5 g) were separated by preparative HPLC $\left(20 \mathrm{~mL} \min ^{-1}, 70 \% \mathrm{MeOH}\right.$ in $\left.\mathrm{H}_{2} \mathrm{O}\right)$ and semipreparative HPLC $\left(2 \mathrm{~mL} \min ^{-1}, 60-90 \% \mathrm{MeOH}\right.$ in $\mathrm{H}_{2} \mathrm{O}$ for $40 \mathrm{~min}$, and followed $40-80 \% \mathrm{MeCN}$ in $\mathrm{H}_{2} \mathrm{O}$ for $40 \mathrm{~min}$ ) to yield 7 (5 mg).

The petroleum ether extract $(140 \mathrm{~g})$ was separated chromatographically on silica gel column $(60-100$ mesh, $16 \times 20$ $\mathrm{cm})$ with a gradient mixture of petroleum ether-ethyl acetate $(100: 1,60: 1,30: 1,15: 1,6: 1$, and $3: 1)$ as eluent. Nine fractions were collected according to TLC analysis. Fraction PE$\mathrm{F}$ (petroleum ether-ethyl acetate, $6: 1,16 \mathrm{~g}$ ) was then subjected to MCI gel CC $(6 \times 50 \mathrm{~cm})$ with a gradient mixture of $\mathrm{MeOH}-$ $\mathrm{H}_{2} \mathrm{O}(60: 40,80: 20$, and $100: 0,4000 \mathrm{~mL}$ each) to give three fractions (Fr.PE-F - Fr. PE-F $F_{3}$. Fraction PE- $F_{2}(10 \mathrm{~g})$ was further separated chromatographically on silica gel column (100-200 


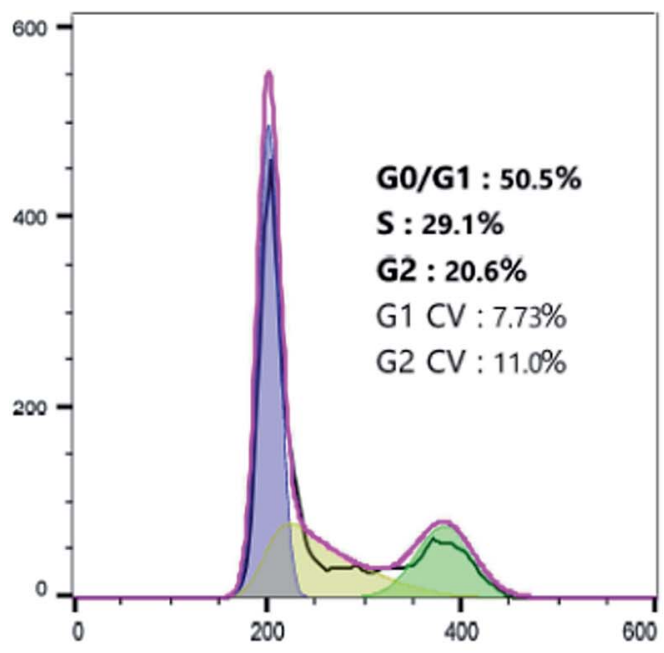

A: Control

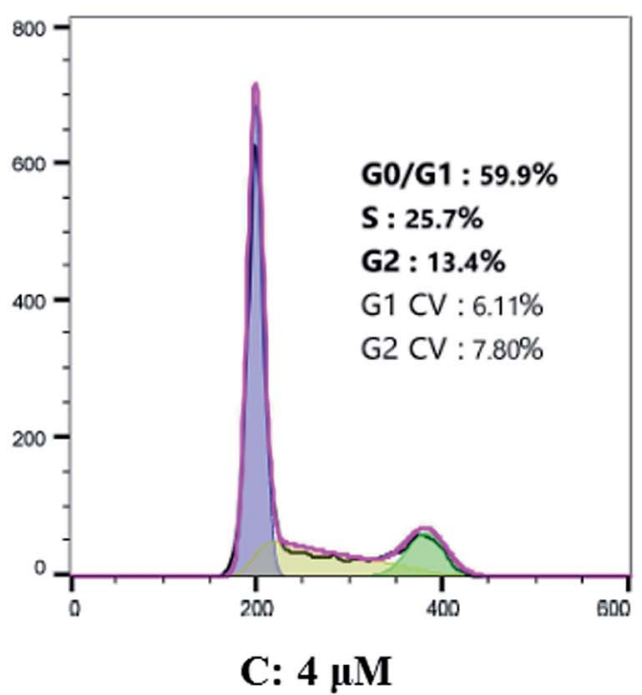

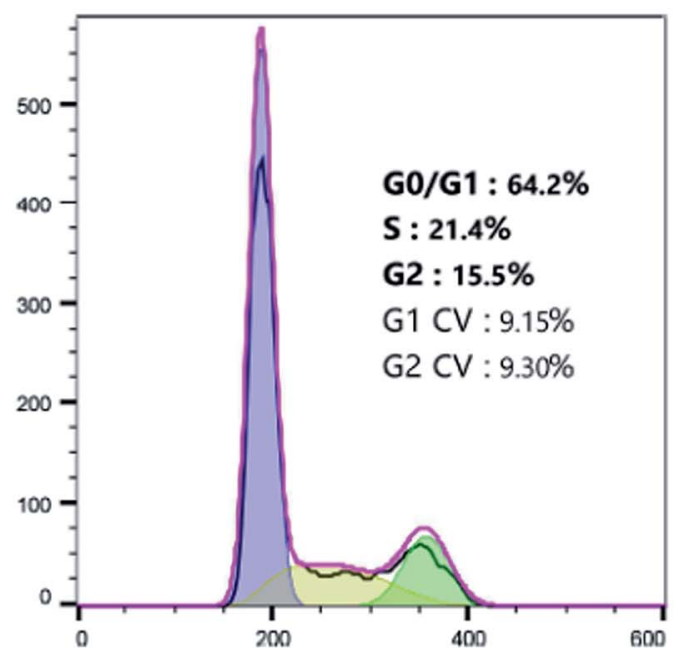

B: $2 \mu \mathrm{M}$

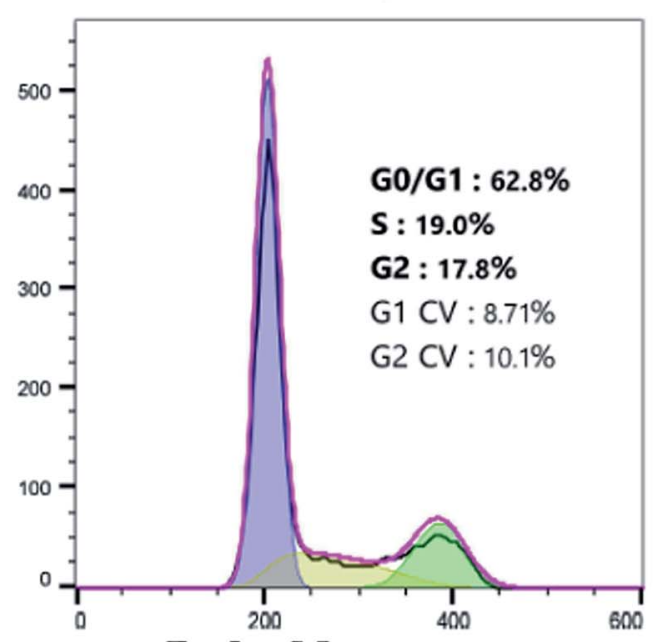

D: $8 \mu \mathrm{M}$

Fig. 9 Effects of cardivarolide H (3) on cell cycle distribution in Hep G2 cells. (A) Control Hep G2 cells; (B) Hep G2 cells treated with $2 \mu$ M 3 ; (C) Hep G2 cells treated with $4 \mu M$ 3; (D) Hep G2 cells treated with $8 \mu M 3$.

mesh, $5 \times 50 \mathrm{~cm}$ ) with a gradient mixture of petroleum etheracetone $(100: 1,25: 1,10: 1$, and $2: 1)$ as eluent, and a total of 4 fractions (Fr.PE- $\mathrm{F}_{2} \mathrm{~A}_{1}-$ Fr.PE- $\mathrm{F}_{2} \mathrm{~A}_{4}, 3000 \mathrm{~mL}$ each) were collected. Fraction Fr.PE- $\mathrm{F}_{2} \mathrm{~A}_{2}(3 \mathrm{~g})$ were separated by preparative HPLC $\left(20 \mathrm{~mL} \min ^{-1}, 80 \% \mathrm{MeOH}\right.$ in $\mathrm{H}_{2} \mathrm{O}$ ) and semipreparative HPLC $\left(2 \mathrm{~mL} \min ^{-1}, 70-90 \% \mathrm{MeOH}\right.$ in $\mathrm{H}_{2} \mathrm{O}$ for $30 \mathrm{~min}$, and followed $40-80 \% \mathrm{MeCN}$ in $\mathrm{H}_{2} \mathrm{O}$ for $40 \mathrm{~min}$ ) to yield 1 (35 mg), 2 (5 mg), 4 (5 mg), 5 (5 mg), and 6 (5 mg).

\section{Characterization of new compounds}

8-Isodivarolide $\mathrm{C}(2)$. White needles $\left(\mathrm{CH}_{3} \mathrm{OH}\right),[\alpha]_{\mathrm{D}}^{20}-48.0(c$ 0.025, MeOH); UV (MeOH) $\lambda_{\max }(\log \varepsilon): 206$ (3.72) nm, IR (neat) $\nu_{\text {max }}: 3414,2971,1748,1203 \mathrm{~cm}^{-1}$; CD (MeOH) $214(\Delta \varepsilon-0.529)$, $295(\Delta \varepsilon+0.251) \mathrm{nm}$; HRESIMS (pos.): $m / z 459.1992[\mathrm{M}+\mathrm{Na}]^{+}$ (calcd for $\mathrm{C}_{23} \mathrm{H}_{32} \mathrm{O}_{8} \mathrm{Na}, 459.1995$ ); ${ }^{1} \mathrm{H}$ NMR data, see Table $1,{ }^{13} \mathrm{C}$ NMR data, see Table 2 .
Cardivarolide $\mathbf{H}$ (3). White needles $\left(\mathrm{CH}_{3} \mathrm{OH}\right),[\alpha]_{\mathrm{D}}^{20}-120.0(c$ $0.075, \mathrm{MeOH})$; UV (MeOH) $\lambda_{\max }(\log \varepsilon): 215$ (3.97) nm, IR (neat) $\nu_{\max }: 3430,2968,2921,1653,1636 \mathrm{~cm}^{-1}$; CD $(\mathrm{MeOH}) 215(\Delta \varepsilon$ -0.083), 308 ( $\Delta \varepsilon-0.013) \mathrm{nm}$; HRESIMS (pos.): $\mathrm{m} / \mathrm{z} 489.2101[\mathrm{M}$ $+\mathrm{Na}]^{+}$(calcd for $\mathrm{C}_{24} \mathrm{H}_{34} \mathrm{O}_{9} \mathrm{Na}, 489.2101$ ); ${ }^{1} \mathrm{H}$ NMR data, see Table $1,{ }^{13} \mathrm{C}$ NMR data, see Table 2.

Cardivarolide I (4). White needles $\left(\mathrm{CH}_{3} \mathrm{OH}\right),[\alpha]_{\mathrm{D}}^{20}-102.0(c$ 0.1, MeOH); UV (MeOH) $\lambda_{\max }(\log \varepsilon): 207$ (4.18) nm, IR (neat) $\nu_{\text {max }}: 3454,2965,1741,1154 \mathrm{~cm}^{-1}$; CD $(\mathrm{MeOH}) 215(\Delta \varepsilon-0.193)$, $307(\Delta \varepsilon-0.035) \mathrm{nm}$; HRESIMS (pos.): $m / z 491.2249[\mathrm{M}+\mathrm{Na}]^{+}$ (calcd for $\mathrm{C}_{24} \mathrm{H}_{36} \mathrm{O}_{9} \mathrm{Na}, 491.2257$ ); ${ }^{1} \mathrm{H}$ NMR data, see Table $1,{ }^{13} \mathrm{C}$ NMR data, see Table 2.

Cardivarolide J (5). White needles $\left(\mathrm{CH}_{3} \mathrm{OH}\right),[\alpha]_{\mathrm{D}}^{20}-123.0(c$ 0.1, MeOH); UV (MeOH) $\lambda_{\max }(\log \varepsilon): 214$ (5.12) nm, IR (neat) $\nu_{\max }: 3464,1749,1157 \mathrm{~cm}^{-1}$; CD $(\mathrm{MeOH}) 215(\Delta \varepsilon-0.187), 308$ $(\Delta \varepsilon-0.028) \mathrm{nm}$; HRESIMS (pos.): $m / z$ 489.2101 [M $+\mathrm{Na}]^{+}$(calcd for $\mathrm{C}_{24} \mathrm{H}_{34} \mathrm{O}_{9} \mathrm{Na}$, 489.2107); ${ }^{1} \mathrm{H}$ NMR data, see Table $1,{ }^{13} \mathrm{C}$ NMR data, see Table 2 . 
Cardivarolide K (6). White needles $\left(\mathrm{CH}_{3} \mathrm{OH}\right),[\alpha]_{\mathrm{D}}^{20}-89.0(c$ 0.1, MeOH); UV (MeOH) $\lambda_{\max }(\log \varepsilon): 216$ (5.53) nm, IR (neat) $\nu_{\text {max }}: 3475,2971,1717,1142 \mathrm{~cm}^{-1}$; CD $(\mathrm{MeOH}) 219(\Delta \varepsilon-0.183)$, $308(\Delta \varepsilon-0.024) \mathrm{nm}$; HRESIMS (pos.): $m / z 501.2101[\mathrm{M}+\mathrm{Na}]^{+}$ (calcd for $\mathrm{C}_{25} \mathrm{H}_{34} \mathrm{O}_{9} \mathrm{Na}, 501.2103$ ); ${ }^{1} \mathrm{H}$ NMR data, see Table $1,{ }^{13} \mathrm{C}$ NMR data, see Table 2.

Cardivarolide L (7). White needles $\left(\mathrm{CH}_{3} \mathrm{OH}\right),[\alpha]_{\mathrm{D}}^{20}+84.7(c$ 0.150, MeOH); UV (MeOH) $\lambda_{\max }(\log \varepsilon): 200$ (3.53) nm, IR (neat) $\nu_{\text {max }}: 3438,3390,1636 \mathrm{~cm}^{-1}$; CD $(\mathrm{MeOH}) 208(\Delta \varepsilon+0.083), 232$ $(\Delta \varepsilon-0.012) \mathrm{nm}$; HRESIMS (pos.): $m / z 389.1575[\mathrm{M}+\mathrm{Na}]^{+}$(calcd for $\left.\mathrm{C}_{19} \mathrm{H}_{26} \mathrm{O}_{7} \mathrm{Na}, 389.1576\right) ;{ }^{1} \mathrm{H}$ NMR data, see Table $1,{ }^{13} \mathrm{C}$ NMR data, see Table 2 .

\section{X-ray crystal structure analysis}

X-ray diffraction data were collected on the Agilent GEMINI ${ }^{\mathrm{TM}} \mathrm{E}$ instrument (CrysAlisPro software, Version 1.171.35.11), with enhanced $\mathrm{Cu} \mathrm{K} \alpha$ radiation $(\lambda=1.54184 \AA)$. The structure was solved by direct methods and refined by full-matrix leastsquares techniques (SHELXL-97). All non-hydrogen atoms were refined with anisotropic thermal parameters. Hydrogen atoms were located by geometrical calculations and from positions in the electron density maps. Crystallographic data (excluding structure factors) for $\mathbf{1}$ and $\mathbf{3}$ in this paper have been deposited with the Cambridge Crystallographic Data Centre (deposition numbers CCDC 1585969 and 1841157).

A colorless orthorhombic crystal $(0.25 \times 0.14 \times 0.13 \mathrm{~mm})$ of 1 was grown from $\mathrm{MeOH}-\mathrm{CH}_{2} \mathrm{Cl}_{2}$ (7:3). Crystal data: $\mathrm{C}_{23} \mathrm{H}_{34} \mathrm{O}_{8}$, $M=438.50, T=104.4 \mathrm{~K}$, orthorhombic, space group $P 2_{1} 2_{1} 2_{1}$,

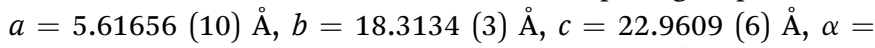
$90.00^{\circ}, \beta=90.00^{\circ}, \gamma=90.00^{\circ}, V=2361.72(2) \AA^{3}, Z=4, \rho=$ $1.233 \mathrm{mg} \mathrm{mm}^{-3}, \mu(\mathrm{Cu} \mathrm{K} \alpha)=0.766 \mathrm{~mm}^{-1}$, measured reflections $=7993$, unique reflections $=4456\left(R_{\mathrm{int}}=0.0275\right)$, largest difference peak/hole $=0.222 /-0.226 \mathrm{e}^{-3}$, and flack parameter $=0.06$ (11). The final $R$ indexes $[I>2 \sigma(I)]$ were $R_{1}=0.0384$, and $\mathrm{w} R_{2}=0.0973$. The final $R$ indexes (all data) were $R_{1}=0.0407$, and $\mathrm{w} R_{2}=0.1000$. The goodness of fit on $F^{2}$ was 1.025 .

A colorless orthorhombic crystal $(0.4 \times 0.36 \times 0.11 \mathrm{~mm})$ of 3 was grown from $\mathrm{CD}_{3} \mathrm{OD}$. Crystal data: $\mathrm{C}_{24} \mathrm{H}_{34} \mathrm{O}_{9}, M=466.51, T$ $=109.45 \mathrm{~K}$, orthorhombic, space group $P 2{ }_{1} 2_{1} 2_{1}, a=9.8307$ (12)

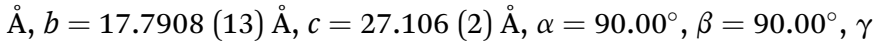
$=90.00^{\circ}, V=4740.8(8) \AA^{3}, Z=8, \rho=1.307 \mathrm{mg} \mathrm{mm}^{-3}, \mu(\mathrm{Cu} \mathrm{K} \alpha)$ $=0.830 \mathrm{~mm}^{-1}$, measured reflections $=18022$, unique reflections $=8922\left(R_{\text {int }}=0.0306\right)$, largest difference peak $/$ hole $=$ $0.488 /-0.371 \mathrm{e}^{-3}$, and flack parameter $=-0.07$ (9). The final $R$ indexes $[I>2 \sigma(I)]$ were $R_{1}=0.0459$, and $\mathrm{w} R_{2}=0.1181$. The final $R$ indexes (all data) were $R_{1}=0.0494$, and $\mathrm{w} R_{2}=0.1213$. The goodness of fit on $F^{2}$ was 1.037 .

\section{Reagents and antibodies}

3-(4,5-Dimethylthiazol-2-yl)-2,5-diphenyltetrazolium bromide (MTT), RNase A, propidium iodide (PI) were purchased from Sigma-Aldrich (MO, USA). Dulbecco's Modified Eagle's Medium (DMEM), RPMI 1640 medium, trypsin, penicillin, streptomycin, fetal bovine serum (FBS) were purchased from Gibco (CA, USA).

The Annexin V-FITC apoptosis detection kit was obtained from Solarbio (Beijing, China).

\section{Cytotoxicity viability assays}

The assay was run in triplicate. The HeLa, Hep G2 and A549 cell lines were obtained from the National Infrastructure of Cell Line Resource (Beijing, China). Cells were cultured in RPMI1640 containing $10 \%$ FBS, 2 mmol per L glutamine, $100 \mathrm{U}$ per $\mathrm{mL}$ penicillin, and $100 \mu \mathrm{g}$ per $\mathrm{mL}$ streptomycin at $37^{\circ} \mathrm{C}$ in a humidified atmosphere with $5 \% \mathrm{CO}_{2}$. The cells were seeded at a density of $5 \times 10^{3}$ cells per well in 96-well plates and allowed to attach for $24 \mathrm{~h}$. The thiazolyl blue tetrazolium blue (MTT) assay was performed to quantify cell viability following treatment with the isolated compounds or reference compound vorinostat. ${ }^{31}$ After $48 \mathrm{~h}, 20 \mathrm{~mL}$ MTT ( $5 \mathrm{mg} \mathrm{mL}{ }^{-1}$ ) solution was added for $4 \mathrm{~h}$ at $37^{\circ} \mathrm{C}$. Then, the supernatant was discarded and dimethylsulfoxide (DMSO) was added to dissolve the formazan product. The intensity was measured at a wavelength of $540 \mathrm{~nm}$.

\section{Morphological analysis with fluorescence microscopy}

Apoptosis is one of the major pathways leading to cell death, and is associated with classical morphologies, including chromatin condensation and nuclear fragmentation. To evaluate the apoptotic activity of $\mathbf{3}$, we performed nuclear staining with the DNA-binding dye, Hoechst-33342. Briefly, K562/A02 cells were plated into 6 -well plates $\left(1 \times 10^{5}\right.$ cells in $\left.3 \mathrm{~mL}\right)$ and treated with $0,2.0,4.0$ or $6.0 \mu \mathrm{M}$ of 3 for $48 \mathrm{~h}$. Cells were collected by centrifugation at $1000 \times g$ for $5 \mathrm{~min}$, washed with ice-cold PBS and then incubated with Hoechst-33342 $\left(10 \mu \mathrm{g} \mathrm{mL}{ }^{-1}\right)$ for 15 min in the dark, then placed on slides, and observed under a fluorescence microscope (excitation $346 \mathrm{~nm}$, emission $460 \mathrm{~nm}$; NIKON TE2000-E). Apoptotic cells were identified by condensation of chromatin and fragmentation of nuclei. Pictures were obtained using a video camera Q-imaging (Burnaby, BC, Canada).

\section{Apoptosis analysis}

Cardivarolide H (3) induced apoptosis in Hep G2 cells were detected using Annexin V-FITC/PI apoptosis staining by flow cytometry. Cells were plated and treated with $3(0,2,4,8 \mu \mathrm{M})$ for $24 \mathrm{~h}$. After harvested and washed twice with cold PBS, the cells were incubated with Annexin V in binding buffer for $10 \mathrm{~min}$ at room temperature in the dark, followed by PI for $5 \mathrm{~min}$. Stained cells were detected and analyzed using FACS Calibur flow cytometry (Becton Dickinson, USA). Apoptotic rates were reported as the percentage of apoptotic cells among total cells.

\section{Cell cycle analysis}

Cell cycle distribution was measured by staining DNA with PI. Cells $\left(1 \times 10^{6}\right)$ were seeded in 6-well plates and treated with $3(0$, $2,4,8 \mu \mathrm{M})$ for $24 \mathrm{~h}$. Then cells were harvested and fixed with $70 \%$ ethanol at $-20{ }^{\circ} \mathrm{C}$ overnight. After washing twice with PBS, the cells were treated with RNase A for $20 \mathrm{~min}$ and then stained with PI (50 $\mathrm{mg} \mathrm{L}^{-1}$ ) for $10 \mathrm{~min}$ in the dark at room temperature. ${ }^{32}$ The distribution of each phase in the cell cycle measured by DNA content was detected using FACS Calibur flow cytometry and analyzed by ModFit LT 4.0 software. 


\section{Conclusion}

In this work, six new highly oxygenated germacranolides (2-7), as well as one known analog (1) were isolated from the whole plant of $C$. divaricatum. Notably, a pair of isomers (3/5) was obtained from the same plant. The absolute configurations of 1 and 3 were unambiguously established by X-ray diffraction. The other compounds with the same skeleton were determined by comparison of NOESY and CD data with those of $\mathbf{1}$ and 3, respectively. To the best of our knowledge, it was the first report of the substituted groups linkage to C-8 of subtype IV, and 7 is the first $14 \alpha$-methylgermacranolide of subtypes I and II. These findings are an important addition to the present knowledge on the germacranolide family. After screening, we found $\mathbf{3}$ and $\mathbf{6}$ showed significant cytotoxicity against two tumor cell lines, respectively. Further studies indicate that the possible mechanism of 3 , was associated with reduced proliferation, induction of apoptosis and G0/G1 phase arrest, as revealed by colorimetric tests, morphological analysis, and flow cytometry. Therefore, novel compound 3 could be treated as a potential candidate for anticancer agents for further study.

\section{Conflicts of interest}

The authors declare no conflict of interest.

\section{Acknowledgements}

This work was financially supported by the Natural Sciences Foundation of Beijing (7194297), the CAMS Innovation Fund for Medical Sciences (CIFMS, 2016-I2M-1-010 and 2016-I2M-2-003), and the Chinese National S\&T Special Project on Major New Drug Innovation (2017ZX09301059).

\section{Notes and references}

1 J. Wang, Y. S. Zhang, K. Thakur, S. S. Hussian, J. G. Zhang, G. R. Xiao and Z. J. Wei, Food Chem. Toxicol., 2018, 120, 407-417.

2 M. F. Yuen, J. L. Hou and A. Chutaputti, Asia Pacific Working Party on Prevention of Hepatocellular Carcinoma, $J$. Gastroenterol. Hepatol., 2009, 24, 346-353.

3 J. Fu and H. Y. Wang, Cancer Lett., 2018, 412, 283-288.

4 H. Cui, Q. Q. Gao, L. Zhang, F. Feng and L. Wang, Life Sci., 2018, 213, 66-73.

5 D. J. Mabberley, Mabberley's Plant Book, Cambridge University Press, Cambridge, 3rd edn, 2008, p. 154.

6 J. P. Zhang, G. W. Wang, X. H. Tian, Y. X. Yang, Q. X. Liu, L. P. Chen, H. L. Li and W. D. Zhang, J. Ethnopharmacol., 2015, 163, 173-191.

7 Editorial board of Chinese Materia Medica, Chinese Materia Medica, Shanghai Science \& Technology Press, Shanghai, 1999, vol. 21, p. 761.
8 E. J. Kim, H. K. Jin, Y. K. Kim, H. Y. Lee, S. Y. Lee, K. R. Lee, O. P. Zee, J. W. Han and H. W. Lee, Biochem. Pharmacol., 2001, 61, 903-910.

9 O. P. Zee, D. K. Kim, S. U. Choi, C. O. Lee and K. R. Lee, Arch. Pharmacal Res., 1999, 22, 225-227.

10 O. P. Zee, D. K. Kim and K. R. Lee, Arch. Pharmacal Res., 1998, 21, 618-620.

11 I. M. Chung, S. H. Seo, E. Y. Kang, W. H. Park, S. D. Park and H. I. Moon, Phytother. Res., 2010, 24, 451-453.

12 D. K. Kim, N. I. Beak, S. U. Choi, C. O. Lee, K. R. Lee and O. P. Zee, J. Nat. Prod., 1997, 60, 1199-1202.

13 M. Maruyama, Phytochemistry, 1990, 29, 547-550.

14 D. K. Kim, K. R. Lee and O. P. Zee, Phytochemistry, 1997, 46, 1245-1247.

15 W. D. Xie, X. R. Wang, L. S. Ma, X. Li and K. H. Row, Fitoterapia, 2012, 83, 1351-1355.

16 H. J. Lee, H. Jung, J. Kwon, H. Li, D. Y. Lee, H. J. Lim, M. R. Kim, D. C. Moon and J. H. Ryu, Can. J. Physiol. Pharmacol., 2011, 89, 232-237.

17 H. I. Moon and O. Zee, Rec. Nat. Prod., 2010, 4, 3149-3155.

18 H. I. Moon and O. Zee, Hum. Exp. Toxicol., 2010, 30, 10831087.

19 R. N. Baruah, R. P. Sharma and G. Thyagarajan, J. Org. Chem., 1980, 45, 4838-4843.

20 N. C. Baruah, R. N. Baruah, R. P. Sharma and J. N. Baruah, J. Org. Chem., 1982, 47, 137-140.

21 A. C. Goswami, R. N. Baruah, R. P. Sharma, J. N. Baruah, P. Kulanthaivel and W. Herz, Phytochemistry, 1984, 23, 367-372.

22 F. Y. Wang, X. Q. Li, Q. Sun, S. Yao, C. Q. Ke, C. P. Tang, H. C. Liu, M. Y. Geng and Y. Ye, Phytochem. Lett., 2012, 5, 639-642.

23 A. G. Gonzalez, J. B. Barrera, J. T. Mendez, J. E. Martinez and M. L. Sanchez, Phytochemistry, 1992, 31, 330-331.

24 A. G. Gonzalez and J. Bermejo, J. Nat. Prod., 1995, 58, 432437.

25 X. Gao, C. J. Lin and Z. J. Jia, J. Nat. Prod., 2007, 70, 830-834. 26 Y. L. Lin and J. C. Ou, J. Nat. Prod., 1996, 59, 991-993.

27 T. Zhang, J. H. Chen, J. G. Si, G. Ding, Q. B. Zhang, H. W. Zhang, H. M. Jia and Z. M. Zou, Sci. Rep., 2018, 8, 12418.

28 Q. X. Liu, Y. X. Yang, J. P. Zhang, L. P. Chen, Y. H. Shen, H. L. Li and W. D. Zhang, J. Nat. Prod., 2016, 10, 2479-2486.

29 J. W. Wu, C. P. Tang, Y. Y. Cai, C. Q. Ke, L. G. Lin, S. Yao and Y. Ye, Chin. Chem. Lett., 2017, 28, 927-930.

30 W. Stochlin, T. G. Waddell and T. A. Geissman, Tetrahedron, 1970, 29, 2397-2409.

31 B. J. Wang, S. J. Won, Z. R. Su and C. L. Yu, Food Chem. Toxicol., 2005, 43, 543-552.

32 N. N. Danial, Clin. Cancer Res., 2007, 13, 7254-7263. 